\title{
The Emerging Role of Electrophiles as a Key Regulator for Endoplasmic Reticulum (ER) Stress
}

\author{
Nobumasa Takasugi, Hideki Hiraoka, Kengo Nakahara ${ }^{\circledR}$, Shiori Akiyama, Kana Fujikawa, \\ Ryosuke Nomura, Moeka Furuichi and Takashi Uehara * \\ Department of Medicinal Pharmacology, Graduate School of Medicine, Dentistry, and Pharmaceutical Sciences, \\ Okayama University, Okayama 700-8530, Japan; ntakasu@okayama-u.ac.jp (N.T.); \\ p4dz03d5@s.okayama-u.ac.jp (H.H.); p4c57y1g@s.okayama-u.ac.jp (K.N.); prjy22tg@s.okayama-u.ac.jp (S.A.); \\ ph426128@s.okayama-u.ac.jp (K.F.); p01107rk@s.okayama-u.ac.jp (R.N.); pqus4tlp@s.okayama-u.ac.jp (M.F.) \\ * Correspondence: uehara-t@okayama-u.ac.jp
}

Received: 8 March 2019; Accepted: 8 April 2019; Published: 10 April 2019

\begin{abstract}
The unfolded protein response (UPR) is activated by the accumulation of misfolded proteins in the endoplasmic reticulum (ER), which is called ER stress. ER stress sensors PERK, IRE1, and ATF6 play a central role in the initiation and regulation of the UPR; they inhibit novel protein synthesis and upregulate ER chaperones, such as protein disulfide isomerase, to remove unfolded proteins. However, when recovery from ER stress is difficult, the UPR pathway is activated to eliminate unhealthy cells. This signaling transition is the key event of many human diseases. However, the precise mechanisms are largely unknown. Intriguingly, reactive electrophilic species (RES), which exist in the environment or are produced through cellular metabolism, have been identified as a key player of this transition. In this review, we focused on the function of representative RES: nitric oxide (NO) as a gaseous RES, 4-hydroxynonenal (HNE) as a lipid RES, and methylmercury (MeHg) as an environmental organic compound RES, to outline the relationship between ER stress and RES. Modulation by RES might be a target for the development of next-generation therapy for ER stress-associated diseases.
\end{abstract}

Keywords: reactive electrophiles; ER stress; UPR; nitric oxide; 4-hydroxynonenal; methylmercury

\section{Endoplasmic Reticulum (ER) Stress and Electrophiles}

The ER is a fundamental intracellular organelle that plays a key role in protein production, folding, and homeostasis. When protein folding is impaired, misfolded proteins accumulate in the ER. In the course of this accumulation, "ER stress" is induced, and the unfolded protein response (UPR) is activated. The UPR is an adaptive system designed to handle misfolded proteins in the ER [1]. The UPR promotes the folding or removal of unfolded proteins by translational repression, transcriptional activation of ER chaperones, and ER-associated degradation (ERAD) [2]. However, under excess or chronic ER stress, the UPR shifts signaling from the protective pathway to the apoptotic pathway, to eliminate unhealthy cells. Although disruption of these pathways is related to many human diseases, such as cancers, diabetes, and neurodegenerative diseases, when and how this shift in signaling takes place remain largely unclear.

Reactive electrophile species (RES) are molecules that have the ability to attract electrons to bond to nucleophiles-molecules with the property of supplying an electron pair [3]. RES, which exist in the environment or are generated by cellular metabolism, covalently bond to their targets, such as DNA and proteins, to alter their structures and physiological functions [4]. As described in the following sections, most RES modifications are reversible and occur in response to the surrounding environment, and RES can also regulate physiological conditions that are essential for maintaining homeostasis. 
However, when the balance of these mechanisms is disrupted, a pathological state is formed. Malignant neoplasms, diabetes mellitus, and neurodegenerative diseases, including Alzheimer's disease (AD), Parkinson's disease (PD), and amyotrophic lateral sclerosis (ALS), have been reported as candidate diseases involving RES. The relationship between these diseases and RES is reviewed elsewhere [5-8].

Intriguingly, it has been gradually identified that modulation of ER stress by RES is a critical pathogenic event for these diseases $[9,10]$. In this review, we discuss the modulation of ER stress by representative RES and provide an overview of their relationship and association with human diseases. We begin with the most analyzed gaseous RES, nitric oxide (NO), followed by lipid RES, 4-hydroxynonenal (HNE), and finally discuss one of the most critical environmental organic compounds RES, methylmercury (MeHg).

\section{NO and ER Stress}

\subsection{Physiological Properties and Functions of NO}

NO is a gaseous molecule with a short half-life that can easily pass through the plasma membrane to regulate various cellular responses, such as apoptosis, proliferation, and neurotransmission [11-17]. Some of these events play essential roles in biological processes, such as the regulation of blood pressure and memory formation [18-20]. NO is intracorporeally synthesized from L-arginine by nitric oxide synthases (NOS), which consist of three isoforms: neuronal NOS (nNOS, NOS1), inducible NOS (iNOS, NOS2), and endothelial NOS (eNOS, NOS3) [21,22]. nNOS and eNOS are characterized by tissue-specific localization, whereas iNOS is broadly expressed in response to inflammation [22]. iNOS is upregulated by bacterial pathogens or immunostimulating cytokines and generates high NO concentrations.

By reacting with oxygen and water, $\mathrm{NO}$ is metabolized into nitrite and nitrate. $\mathrm{NO}$ and these metabolites are called reactive nitrogen species and have free oxygen radicals, which cause high electrophilic reactivity [12,23-25]. NO attacks the cysteine thiol of various proteins to form $S$-nitrosothiol [26,27]. A target cysteine of $S$-nitrosylation has been suggested to be the thiolate anion, which is located at the acid-base motif $[28,29]$. This modification changes the enzyme activity, stability, or localization of target proteins [30]. Some NO functions have oppositional effects [19,31]. Appropriate amounts of NO contribute to neurotransmitter release or biophylaxis against viral or bacterial infection [32-37]. However, excessive amounts of NO cause abnormal modification of proteins, which are not targeted at steady-state concentrations [8,38-42].

Interestingly, NO differentially modulates ER homeostasis through S-nitrosylation of targeted proteins related to the UPR, such as protein disulfide isomerase (PDI) and inositol-requiring kinase 1 alpha (IRE1 $\alpha$ ) (Figure 1). Here, we describe the association between NO-induced ER stress and various diseases. 


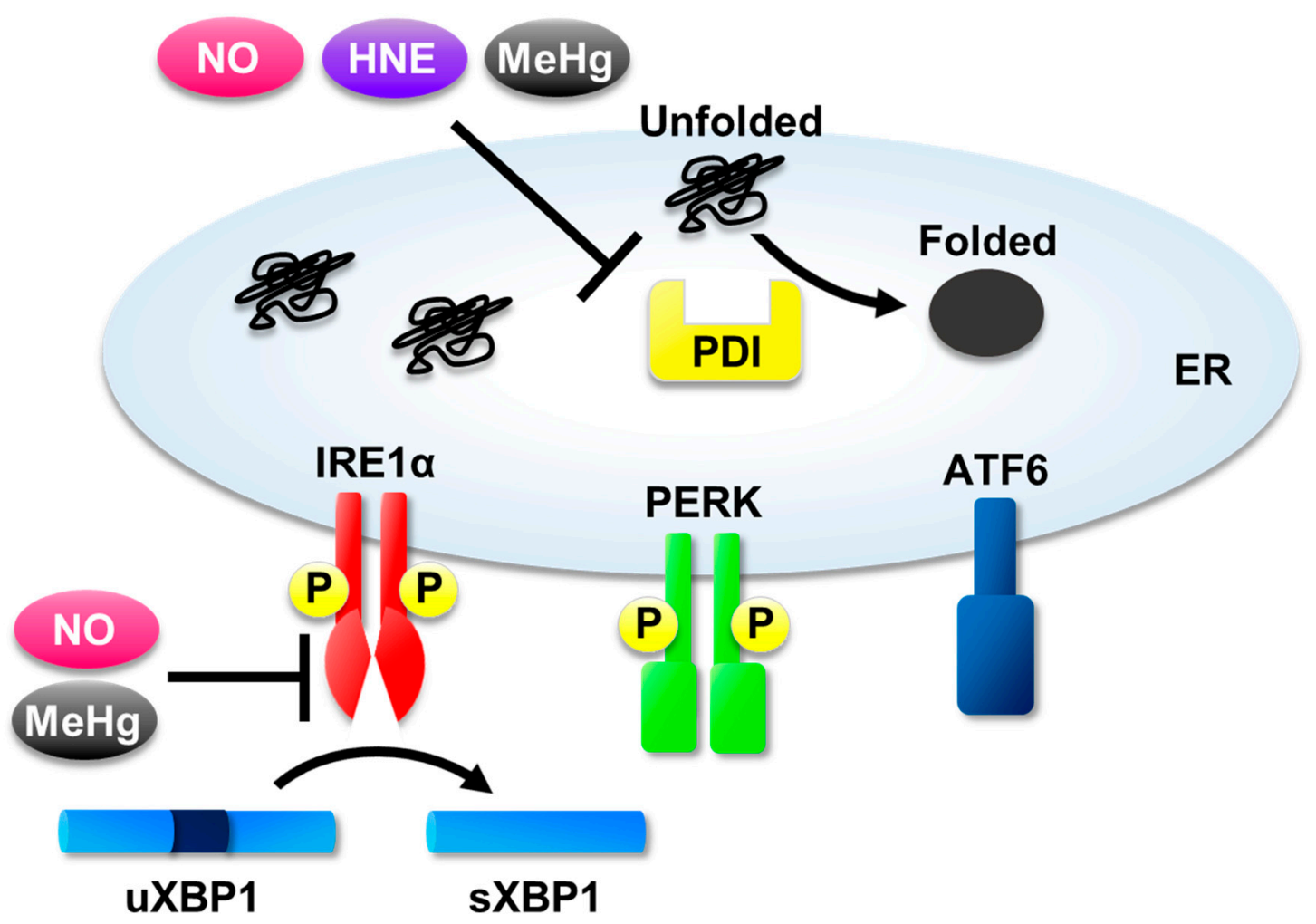

Figure 1. Targets of electrophiles in the unfolded protein response (UPR). NO, nitric oxide; HNE, 4-hydroxynonenal; $\mathrm{MeHg}$, methylmercury; $\mathrm{P}$, phosphate group; top arrow, protein folding process by PDI; lower arrow, RNA splicing process by IRE1 $\alpha$.

\subsection{PDI as a Target for NO}

PDI is an ER chaperone that is mainly localized in the ER and plays a crucial role in protein folding through disulfide bond formation [43]. PDI is comprised of four domains, a, $a^{\prime}, b$, and $b^{\prime}$ domains, and the $\mathrm{C}$-terminal region, which contains many acidic amino acids. The a and a' domains are activation domains, which are separated by two domains, $b$ and $b^{\prime}$ [44]. The activation domains have an active site that consists of four amino acids (Cys-Gly-His-Cys). The oxidoreductase activity of PDI is derived from thiol groups of active site cysteines [45], and each active site (CGHC) is an oxidizing agent in the ER because of the high disulfide reduction potential and low $\mathrm{pK}_{\mathrm{a}}$ (acidity constant) value [46,47].

We previously reported that PDI is S-nitrosylated, which decreases its enzymatic activity and leads to the accumulation of misfolded proteins, subsequently inducing ER stress [48]. S-nitrosylation of PDI occurs in redox-active thiols, inhibiting its enzymatic activity to result in the accumulation of polyubiquitinated proteins, an increase in ER stress, and the induction of apoptosis. Taken together, PDI is a crucial regulator for intracellular redox balance that is disrupted by excessive amounts of NO.

Intriguingly, this modification is promoted in chronic and aging-associated diseases, especially neurodegenerative diseases, during which misfolded proteins accumulate in the affected area. AD is characterized by the aggregation of amyloid- $\beta(A \beta)$ plaque and neurofibrillary tangles containing abnormally phosphorylated tau [49]. These features contribute to inflammation-induced iNOS expression and then ER stress [50]. In AD, nNOS is also upregulated by the increased calcium ion $\left(\mathrm{Ca}^{2+}\right)$ influx, which is mediated by the activation of $N$-methyl-D-aspartate (NMDA)-type glutamate receptor. The activation of iNOS and nNOS leads to the upregulation of S-nitrosylated (SNO)-PDI levels in AD patients [48]. Furthermore, $\mathrm{A} \beta$ causes neurotoxicity via oxidative stress, mitochondrial dysfunction, and aggregation of misfolded proteins [51,52]. A recent study reported that $A \beta$ injection into the rat brain increased SNO-PDI and induced ER stress-mediated apoptosis [53]. Additionally, SNO-PDI existed in neurofibril tangles [54]. 
ER stress and nitrosative stress have also been implicated in the pathogenesis of PD [55]. Recently, some studies indicated that SNO-PDI contributes to oligomerization and aggregation of $\alpha$-synuclein, which is a major component of Lewy body inclusion in the brain [56,57]. Also, rotenone, a pesticide, causes neurotoxicity via mitochondria complex I inhibition, and induced iNOS expression [58]. Rotenone-induced iNOS expression increases SNO-PDI formation, subsequently leading to apoptotic cell death. Moreover, we reported that the NO- and PD-inducing agent $\mathrm{MPP}^{+}$caused S-nitrosylation of IRE1 $\alpha$, in addition to PDI, in human neuroblastoma cells [59].

Similar to AD and PD, ALS is characterized by the presence of inclusions containing aggregated proteins, such as superoxide dismutase 1 (SOD1) [60]. SNO-PDI is also increased in ALS patients and contributes to the onset and development of ALS [61]. Moreover, the SOD1 G93A mutant protein, representing a type of familial ALS gene mutation, aggregated and accumulated via SNO-PDI activity $[62,63]$. These results indicate that nitrosative stress induces ER stress mediated by SNO-PDI and, consequently, neuronal cell death.

\subsection{IRE1 $\alpha$ as a Target for NO}

The amount of ER stress is monitored by transmembrane proteins, which act as ER stress sensors. The UPR is activated by three ER sensors: protein kinase R (PKR)-like endoplasmic reticulum kinase (PERK), inositol-requiring kinase 1 (IRE1), and activating transcription factor 6 (ATF6).

PERK dimerizes or oligomerizes to induce autophosphorylation and activation. When activated, PERK phosphorylates eukaryotic initiation factor $2 \alpha$ (eIF2 $\alpha$ ) to induce translational repression [64]. Conversely, phosphorylated eIF2 $\alpha$ promotes translation of activating transcription factor 4 (ATF4) to express ER chaperones, such as PDI [65]. ATF4 also activates various genes that are involved in cellular processes, such as autophagy and the antioxidant response [66]. IRE1 $\alpha$ is activated by a similar process as PERK; it dimerizes or oligomerizes to induce autophosphorylation [2]. IRE1 $\alpha$ reduces protein synthesis in the ER by regulated IRE1 $\alpha$-dependent decay (RIDD) [67]. IRE1 $\alpha$ also catalyzes splicing of X-box binding protein 1 (XBP1) mRNA [66]. Spliced XBP1 is a transcription factor that induces the upregulation of ER chaperones and proteins involved in the ERAD pathway [68]. A third pathway, ATF6, is activated by cleavage in Golgi bodies. ATF6 translocates from the ER membrane to the Golgi body, where it is cleaved by site- 1 and site- 2 proteases. The cytosolic ATF6 fragment, which contains a basic-leucine zipper domain, translocates to the nucleus and induces the expression of target genes that encode ER chaperones, proteins involved in ERAD, and XBP1 [69].

We and others reported SNO-IRE1 $\alpha$ formation in cysteine residues within the kinase-extension nuclease (KEN) domain that carries out a ribonuclease function [70,71]. These modifications affected XBP1 splicing but did not affect IRE1 $\alpha$ oligomerization and phosphorylation [59,72]. In contrast to this disruption of the IRE1 $\alpha-X B P 1$ pathway, NO does not affect the PERK and ATF6 branches [59,72]. The IRE1 $\alpha-X B P 1$ branch acts as an anti-apoptotic pathway, whereas the PERK and ATF6 branches are implicated in cell death. Therefore, SNO-IRE1 $\alpha$ leads to ER stress associated with neuronal cell death. These studies suggested that NO contributes to the pathology of PD mediated by S-nitrosylation of various target proteins.

Type II diabetes and obesity are characterized by dysfunctional insulin signaling, which is implicated in chronic inflammation and ER stress [72-74]. Indeed, inflammation-associated iNOS expression is elevated in obesity and type II diabetes $[75,76]$. A recent study elucidated that the level of SNO-IRE1 $\alpha$ is increased in high-fat diet induced-diabetes model mice [72]. As described above, SNO modification of IRE1 $\alpha$ inhibits its endonuclease activity, but not phosphorylation. Interestingly, in the obese model established using liver-specific IRE1 $\alpha$-deficient mice, expression of IRE1 $\alpha$ with a nitrosylation-resistant variant more effectively restored XBP1 splicing and improved glucose homeostasis than wild type IRE1 $\alpha$ [72]. Considering that the expression of spliced XBP1 (sXBP1) also improved glucose homeostasis [72], these data suggest that the endonuclease activity of IRE1 $\alpha$ is a critical regulator for the maintenance of glucose homeostasis. Furthermore, other studies reported that insulin resistance is acquired by inflammation, oxidative stress, and ER stress [73,75]. Also, NO can 
S-nitrosylate insulin signaling-related proteins, such as insulin receptor, insulin receptor substrate 1, and RAC-alpha serine/threonine-protein kinase (Akt), to inhibit Akt signaling [77]. These lines of evidence indicate that excessive or prolonged $\mathrm{NO}$ contributes not only to ER stress induction but also to insulin resistance.

\section{HNE and ER Stress}

4-Hydroxynonenal (HNE) is one of the major end products derived from the oxidation of polyunsaturated fatty acids (PUFA) by reactive oxygen species (ROS). ROS mostly affect a limited area, due to their high reactivities. Meanwhile, HNE is relatively stable, which enables it to travel a substantial distance from the site of synthesis and work as a second messenger of free radicals. HNE modifies nucleophilic residues of proteins using its three reactive groups: an aldehyde, a double bond between carbon C2 and C3, and a secondary alcohol at carbon C4. Under physiological conditions, HNE regulates several transcription factors, such as nuclear factor erythroid 2-related factor 2 (Nrf2) [78], activating protein-1 (AP-1) [79], and nuclear factor- $\mathrm{K}$ B (NF- $\mathrm{KB}$ ) [80]. HNE also modulates cell signaling pathways, including the protein kinase $C$ [81] and epidermal growth factor receptor (EGFR) pathways [82]. However, prolonged and/or excessive oxidative stress lead to HNE accumulation, thereby disrupting the balance of regulation. High levels of HNE and HNE-modified proteins have been observed in many diseases associated with oxidative stress, such as AD [83,84], PD [85], cardiac/cerebral ischemia [86,87], and alcoholic/non-alcoholic fatty liver disease $[88,89]$. These data suggest that uncontrolled HNE production contributes to cellular dysfunction and disease development.

Given that loss of proteostasis was observed in these diseases [90-92], it has been described that HNE induces ER stress and the UPR, similar to the other electrophiles described above. Indeed, a microarray analysis of human colon cancer cells treated with HNE exhibited significant alterations of gene expression related to ER stress [93]. Nevertheless, the effects of HNE on the UPR differ among studies. HNE activated all three UPR signaling branches in human umbilical vein endothelial cells [94]. By contrast, a survey of primary rat aortic smooth muscle cells treated with HNE showed a significant increase in PERK and eIF2 $\alpha$ phosphorylation, but robust IRE1 $\alpha$ and ATF6 stimulation [95].

The discrepancy between the reported effects of HNE could arise from the difference between the studied species. Additionally, the capability of HNE metabolism differs in cells. Since there are several pathways for metabolizing HNE [96], cells are not all equal regarding HNE detoxification. Therefore, the response and protein modification targets of HNE-treated cells could be different in each cell line and tissue. To further understand the mechanism of HNE-induced ER stress, it is worth noting that HNE reacts with critical players of proteostasis. PDI modification by HNE inhibited its enzymatic activity, resulting in ER stress and apoptosis in endothelial cells [97]. Furthermore, heat shock protein (HSP) 70 and HSP90 were modified by HNE, which led to the inhibition of their folding functions in a rat model of alcoholic liver disease [98,99]. Interestingly, the impairment of HSP proteins is reported to promote ER stress via modulation of IRE1 $\alpha$ activity $[100,101]$ and downregulation of the activity of the carboxy terminus of HSP70-interacting protein (CHIP) which exerts E3 ubiquitin ligase activity associated with ERAD [102,103]. Moreover, HNE modified the 20 S proteasome and suppressed its peptidase activity during coronary occlusion and reperfusion [104].

These studies suggest that HNE-induced disturbance of ER homeostasis could cause apoptosis and disease progression. Although further demonstration of the correlation between protein modification by HNE and disease is required, HNE might be useful as a biological marker to predict or diagnose disease given the association between high HNE concentration and pathological conditions.

\section{MeHg and ER Stress}

$\mathrm{MeHg}$, a known neurotoxicant, is an environmental electrophile. Inorganic mercury is released into the air by gold mining in developing countries, or through volcanic activity. Mercury deposited in the ocean is converted into $\mathrm{MeHg}$ by aquatic microorganisms. $\mathrm{MeHg}$ has biomagnification potential and accumulates to high levels in large predatory fishes, such as whale or tuna. Humans are exposed 
to $\mathrm{MeHg}$ through ingestion of these species [105]. MeHg interacts with L-cysteine and forms the MeHg-L-cysteine complex, which conformationally mimics methionine and easily penetrates the blood-brain barrier via methionine transporters [106]. Although $\mathrm{MeHg}$ has been shown to cause lesions in the central nervous system, the mechanisms of MeHg-induced cell toxicity are not fully understood. In this section, we describe the molecular mechanism associated with MeHg toxicity from the viewpoint of ER stress.

The reactivity of chemical materials is evaluated according to the hard and soft acid and base (HSAB) principle. MeHg and thiolate anion are classified as a soft acid and a soft base, respectively, according to HSAB principles. MeHg strongly conjugates with the thiolate anion due to the high affinity between a soft acid and a soft base. This affinity has been shown to be greater than with various ligands of amino acids, such as a histidine residue [107]. Therefore, it has been suggested that $\mathrm{MeHg}$ toxicity can be attributed to covalent bonding with the thiol group of cysteine residues in proteins (S-mercuration) [108]. MeHg-induced disruption of microtubules and inhibition of protein synthesis have been considered as significant mechanisms involved in MeHg toxicity [109,110]. However, many recent reports mentioned this toxicity from the viewpoint of oxidative stress. For example, $S$-mercuration of manganese superoxide dismutase (MnSOD) located in mitochondria impairs MnSOD activity, resulting in ROS accumulation and mitochondrial dysfunction [111]. Furthermore, glutathione (GSH), which is known to contribute to the elimination of MeHg by GSH conjugation, decreases after high exposure to $\mathrm{MeHg}$, subsequently inducing oxidative stress [112].

UPR, especially the IRE1 $\alpha$ branch, may be linked to the cytotoxicity of MeHg-derived oxidative stress. Apoptosis signal-regulating kinase 1 (ASK1) is a part of the mitogen-activated protein kinase pathway, which is activated in response to various stresses and inactivated by forming a complex with thioredoxin (Trx) at steady-state. However, oxidized Trx dissociates from ASK1 under oxidative stress, resulting in apoptosis induced by activated ASK1 [113]. In a previous study, MeHg-derived accumulation of ROS was shown to evoke ASK1 activation and cause cell death [114]. Moreover, ASK1 has been shown to interact with the IRE1 $\alpha$-TRAF2 complex and induce apoptosis under ER stress [115]. These findings suggest that MeHg-induced cell death is derived from ER stress following induction of oxidative stress [114]. This theory is supported by another research group, which found that Trolox, a known ROS scavenger, inhibits MeHg-induced ER stress [116]. Conversely, we have shown that MeHg induced oxidative modification of PDI, similar to NO [117]. MeHg attenuates the enzymatic activity of PDI by S-mercuration and results in ER stress [117]. Taken together, MeHg elicits ER stress from diverse approaches.

Caspase-12 belongs to the caspase family and is activated by ER stress [118]. MeHg is thought to trigger apoptosis via induction of ER stress caused by caspase activation [114,116]. Additionally, we found that $S$-mercuration of IRE1 $\alpha$ interferes IRE1 $\alpha-$ XBP1 signaling (Figure 1 [119]). Activation of IRE1 $\alpha$-TRAF2-ASK1 pathway was also observed in XBP1-deficient cells [120]. These findings indicate that inhibition of the IRE1 $\alpha-X B P 1$ pathway strongly accelerates cell death.

$\mathrm{MeHg}$ impairs the central nervous system, suggesting that $\mathrm{MeHg}$ is relevant to the onset of neurodegenerative diseases, such as AD, PD, and ALS [121-124]. Additionally, it has been reported that $\mathrm{MeHg}$ affects fetal neurodevelopment via prenatal exposure to MeHg [125]. These nervous system diseases are highly related to ER stress [126-129]. Hence, MeHg-induced ER stress may contribute to the onset of these nervous system diseases. The effect of MeHg on human health is a relevant issue because humans continuously uptake $\mathrm{MeHg}$ via fish consumption. Therefore, elucidating the molecular mechanism of $\mathrm{MeHg}$ toxicity remains important.

\section{Conclusions}

In addition to the RES mentioned above, other RES, such as 1,4-naphthoquinone [130], acrolein [131-133], and electrophilic prostaglandins [134,135], have also been associated with ER stress. These lines of evidence support the idea that RES are the key factor controlling ER stress responses. Although further studies are required to fully elucidate each mechanism, targeting or 
inversely making use of RES modulation of ER stress might be the next generation of therapeutic methodology for associated diseases.

Funding: This work was supported in part by a Grants-in-Aid for Scientific Research (B) 18H02579, Challenging Exploratory Research 17K19490, Scientific Research (S) 17H06170, 18H05293 (to T.U.), and Scientific Research (C) 17K08272 (to N.T.) from the Ministry of Education, Culture, Sports and Technology (MEXT) of Japan, and the Smoking Research Foundation (to T.U.) and Life Science Foundation of Japan (to N.T.).

Conflicts of Interest: The authors declare no conflict of interest.

\section{Abbreviations}

$\mathrm{AD}$

Akt

ALS

AP-1

ASK1

ATF6

$\mathrm{A} \beta$

$\mathrm{Ca}^{2+}$

CHIP

EGFR

eIF2 $\alpha$

eNOS

ER

ERAD

GSH

HNE

HSAB

HSP70

HSP90

iNOS

IRE1 $\alpha$

JNK

KEN

$\mathrm{MeHg}$

MnSOD

$\mathrm{MPP}+$

NF- $\mathrm{kB}$

NMDA

nNOS

$\mathrm{NO}$

NOS

Nrf2

PUFA

PD

PDI

PERK

PKR

RES

RIDD

ROS

SNO

SOD1

TRAF2

Trolox

Trx

UPR

XBP1

Alzheimer's disease

RAC-alpha serine/threonine-protein kinase

Amyotrophic lateral sclerosis

Activating protein-1

Apoptosis signal-regulating kinase 1

Activating transcription factor 6

Amyloid- $\beta$

Calcium ion

Carboxy terminus of HSP70-interacting protein

Epidermal growth factor receptor

Eukaryotic translation factor $2 \alpha$

Endothelial NOS

Endoplasmic reticulum

ER-associated degradation

Glutathione

4-Hydroxynonenal

Hard and soft acid and base

Heat shock protein 70

Heat shock protein 90

Inducible NOS

Inositol-requiring kinase $1 \alpha$

c-Jun N-terminal kinase

Kinase-extension nuclease

Methylmercury

Manganese superoxide dismutase

1-Methyl-4-phenylpyridinium iodide

Nuclear factor-k B

$N$-Methyl-D-aspartate

Neuronal NOS

Nitric oxide

Nitric oxide synthase

Nuclear factor erythroid 2-related factor 2

Polyunsaturated fatty acids

Parkinson's disease

Protein disulfide isomerase

PKR-like endoplasmic reticulum kinase

Protein kinase $\mathrm{R}$

Reactive electrophile species

Regulated IRE1 $\alpha$-dependent decay

Reactive oxygen species

S-Nitrosylated

Superoxide dismutase 1

TNF receptor-associated factor 2

6-Hydroxy-2,5,7,8-tetramethylchroman-2-carboxylic acid

Thioredoxin

Unfolded protein response

X-box binding protein 1 


\section{References}

1. Walker, A.K. Protein Disulfide Isomerase and the Endoplasmic Reticulum in Amyotrophic Lateral Sclerosis. J. Neurosci. 2010, 30, 3865-3867. [CrossRef]

2. Hetz, C. The unfolded protein response: Controlling cell fate decisions under ER stress and beyond. Nat. Rev. Mol. Cell Biol. 2012, 13, 89-102. [CrossRef] [PubMed]

3. Levonen, A.-L.; Hill, B.G.; Kansanen, E.; Zhang, J.; Darley-Usmar, V.M. Redox regulation of antioxidants, autophagy, and the response to stress: Implications for electrophile therapeutics. Free Radic. Biol. Med. 2014, 71, 196-207.

4. Ghoshal, K.; Motiwala, T.; Claus, R.; Yan, P.; Kutay, H.; Datta, J.; Majumder, S.; Bai, S.; Majumder, A.; Huang, T.; et al. HOXB13, a Target of DNMT3B, Is Methylated at an Upstream CpG Island, and Functions as a Tumor Suppressor in Primary Colorectal Tumors. PLoS ONE 2010, 5, e10338.

5. Sakanyan, V. Reactive Chemicals and Electrophilic Stress in Cancer: A Minireview. High-Throughput 2018, 7,12 .

6. Zimniak, P. Free Radical Biology \& Medicine Relationship of electrophilic stress to aging. Free Radic. Biol. Med. 2011, 51, 1087-1105.

7. Groeger, A.L.; Freeman, B.A. Signaling Actions of Electrophiles: Anti-inflammatory Therapeutic Candidates. Mol. Interv. 2010, 10, 39-50. [CrossRef] [PubMed]

8. Nakamura, T.; Prikhodko, O.A.; Pirie, E.; Nagar, S.; Akhtar, M.W.; Oh, C.-K.; McKercher, S.R.; Ambasudhan, R.; Okamoto, S.-I.; Lipton, S.A. Aberrant protein S-nitrosylation contributes to the pathophysiology of neurodegenerative diseases. Neurobiol. Dis. 2015, 84, 99-108. [CrossRef]

9. Kim, I.; Xu, W.; Reed, J.C. Cell death and endoplasmic reticulum stress: Disease relevance and therapeutic opportunities. Nat. Rev. Drug Discov. 2008, 7, 1013-1030. [CrossRef] [PubMed]

10. Hitomi, J.; Katayama, T.; Eguchi, Y.; Kudo, T.; Taniguchi, M.; Koyama, Y.; Manabe, T.; Yamagishi, S.; Bando, Y.; Imaizumi, K.; et al. Involvement of caspase-4 in endoplasmic reticulum stress-induced apoptosis and Abeta-induced cell death. J. Cell Biol. 2004, 165, 347-356. [PubMed]

11. Albina, J.E.; Cui, S.; Mateo, R.B.; Reichner, J.S. Nitric oxide-mediated apoptosis in murine peritoneal macrophages. J. Immunol. 1993, 150, 5080-5085.

12. Liaudet, L.; Soriano, F.G.; Szabó, C. Biology of nitric oxide signaling. Crit. Care Med. 2000, 28, N37-N52. [CrossRef]

13. Wood, J.; Garthwaite, J. Models of the diffusional spread of nitric oxide: Implications for neural nitric oxide signalling and its pharmacological properties. Neuropharmacology 1994, 33, 1235-1244. [CrossRef]

14. Albina, J.E.; Abate, J.A.; Henry, W.L., Jr. Nitric oxide production is required for murine resident peritoneal macrophages to suppress mitogen-stimulated T cell proliferation. Role of IFN-gamma in the induction of the nitric oxide-synthesizing pathway. J. Immunol. 1991, 147, 144-148.

15. Kuzin, B.; Roberts, I.; Peunova, N.; Enikolopov, G. Nitric oxide regulates cell proliferation during Drosophila development. Cell 1996, 87, 639-649. [CrossRef]

16. Maher, A.; Rahman, M.F.; Gad, M.Z. The Role of Nitric Oxide from Neurological Disease to Cancer. Australas. Biotechnol. 2010, 20, 9-10.

17. Montagna, C.; Rizza, S.; Maiani, E.; Piredda, L.; Filomeni, G.; Cecconi, F. To eat, or NOt to eat: S-nitrosylation signaling in autophagy. FEBS J. 2016, 283, 3857-3869. [CrossRef] [PubMed]

18. Moncada, S.; Higgs, A. The L-arginine-nitric oxide pathway. N. Engl. J. Med. 1993, 329, 2002-2012. [PubMed]

19. Picón-Pagès, P.; Garcia-Buendia, J.; Muñoz, F.J. Functions and dysfunctions of nitric oxide in brain. Biochim. Biophys. Acta Mol. Basis Dis. 2018. [CrossRef] [PubMed]

20. Rees, D.D.; Palmer, R.M.J.; Moncada, S. Role of endothelium-derived nitric oxide in the regulation of blood pressure. Proc. Natl. Acad. Sci. USA 1989, 86, 3375-3378. [CrossRef]

21. Moncada, S.; Palmer, R.M.J.; Higgs, E.A. Biosynthesis of nitric oxide from l-arginine. A pathway for the regulation of cell function and communication. Biochem. Pharmacol. 1989, 38, 1709-1715. [CrossRef]

22. Förstermann, U.; Kleinert, H. Nitric oxide synthase: Expression and expressional control of the three isoforms. Naunyn Schmiedebergs Arch. Pharmacol. 1995, 352, 351-364. [CrossRef]

23. Stamler, J.S.; Singel, D.J.; Loscalzo, J. Biochemistry Nitric Oxide and Redox-Activated Forms. Science 1992, 258, 1898-1902. [CrossRef] 
24. Lipton, S.A.; Choi, Y.B.; Pan, Z.H.; Lei, S.Z.; Chen, H.S.V.; Sucher, N.J.; Loscalzo, J.; Singel, D.J.; Stamler, J.S. A redox-based mechanism for the neuroprotective and neurodestructive effects of nitric oxide and related nitroso-compounds. Nature 1993, 364, 626-632. [CrossRef]

25. Palmer, R.M.; Ferrige, A.G.; Moncada, S. Nitric oxide release accounts for the biological activity of endothelium-derived relaxing factor. Nature 1987, 327, 30-32. [CrossRef]

26. Stamler, J.S. Redox signaling: Nitrosylation and related target interactions of nitric oxide. Cell 1994, 78, 931-936. [CrossRef]

27. Jaffrey, S.R.; Erdjument-bromage, H.; Ferris, C.D.; Tempst, P.; Snyder, S.H. Protein S-nitrosylation: A physiological signal for neuronal nitric oxide. Nat. Cell Biol. 2001, 3, 193-197. [CrossRef]

28. Hess, D.T.; Matsumoto, A.; Nudelman, R.; Stamler, J.S. S-nitrosylation: Spectrum and specificity. Nat. Cell Biol. 2001, 3, E46-E49. [CrossRef]

29. Greco, T.M.; Hodara, R.; Parastatidis, I.; Heijnen, H.F.G.; Dennehy, M.K.; Liebler, D.C.; Ischiropoulos, H. Identification of S-nitrosylation motifs by site-specific mapping of the S-nitrosocysteine proteome in human vascular smooth muscle cells. Proc. Natl. Acad. Sci. USA 2006, 103, 7420-7425. [CrossRef]

30. Stamler, J.S.; Toone, E.J.; Lipton, S.A.; Sucher, N.J. (S)NO signals: Translocation, regulation, and a consensus motif. Neuron 1997, 18, 691-696. [CrossRef]

31. Iadecola, C. Bright and dark sides of nitric oxide in ischemic brain injury. Trends Neurosci. 1997, 20, 132-139. [CrossRef]

32. Garthwaite, J. Glutamate, nitric oxide and cell-cell signalling in the nervous system. Trends Neurosci. 1991, 14, 60-67. [CrossRef]

33. Bredt, D.S.; Snyder, S.H. Nitric oxide, a novel neuronal messenger. Neuron 1992, 8, 3-11. [CrossRef]

34. Garthwaite, J. Nitric oxide as a multimodal transmitter in the brain: Discovery and current status. Br. J. Pharmacol. 2019, 176, 197-211. [CrossRef]

35. Wheeler, M.A.; Smith, S.D.; García-Cardeña, G.; Nathan, C.F.; Weiss, R.M.; Sessa, W.C. Bacterial infection induces nitric oxide synthase in human neutrophils. J. Clin. Investig. 1997, 99, 110-116. [CrossRef]

36. Karupiah, G.; Xie, Q.; Buller, R.M.L.; Nathan, C.; Duarte, C.; Macmicking, J.D. Inhibition of viral replication by interferon-gamma-induced nitric oxide synthase. Science 1993, 261, 1445-1448. [CrossRef]

37. Bogdan, C. Nitric oxide and the immune response. Nat. Immunol. 2001, 2, 907-916. [CrossRef]

38. Ialenti, A.; Ianaro, A.; Moncada, S.; Di Rosa, M. Modulation of acute inflammation by endogenous nitric oxide. Eur. J. Pharmacol. 1992, 211, 177-182. [CrossRef]

39. Hofseth, L.J.; Saito, S.; Hussain, S.P.; Espey, M.G.; Miranda, K.M.; Araki, Y.; Jhappan, C.; Higashimoto, Y.; He, P.; Linke, S.P.; et al. Nitric oxide-induced cellular stress and p53 activation in chronic inflammation. Proc. Natl. Acad. Sci. USA 2003, 100, 143-148. [CrossRef]

40. Kaur, H.; Halliwell, B. Evidence for nitric oxide-mediated oxidative damage in chronic inflammation. FEBS Lett. 1994, 350, 9-12. [CrossRef]

41. Eiserich, J.P.; Hristova, M.; Cross, C.E.; Jones, A.D.; Freeman, B.A.; Halliwell, B.; Van Der Vliet, A. Formation of nitric oxide-derived inflammatory oxidants by myeloperoxidase in neutrophils. Nature 1998, 391, $393-397$. [CrossRef]

42. Anand, P.; Stamler, J.S. Enzymatic mechanisms regulating protein S-nitrosylation: Implications in health and disease. J. Mol. Med. 2012, 90, 233-244. [CrossRef]

43. Ellgaard, L.; Ruddock, L.W. The human protein disulphide isomerase family: Substrate interactions and functional properties. EMBO Rep. 2005, 6, 28-32. [CrossRef]

44. Hatahet, F.; Ruddock, L.W. Substrate recognition by the protein disulfide isomerases. FEBS J. 2007, 274, 5223-5234. [CrossRef]

45. Xu, S.; Sankar, S.; Neamati, N. Protein disulfide isomerase: A promising target for cancer therapy. Drug Discov. Today 2014, 19, 222-240. [CrossRef]

46. Wilcox, T.; Hirshkowitz, A. Native Disulfide Bond Formation in Proteins. Curr. Opin. Chem. Biol. 2000, 4, 533-539.

47. Liu, H.; Dong, X.-Y.; Sun, Y. Peptide disulfide RKCGCFF facilitates oxidative protein refolding by mimicking protein disulfide isomerase. Biochem. Eng. J. 2013, 79, 29-32. [CrossRef]

48. Uehara, T.; Nakamura, T.; Yao, D.; Shi, Z.; Gu, Z.; Ma, Y.; Masliah, E.; Nomura, Y.; Lipton, S.A. S-Nitrosylated protein-disulphide isomerase links protein misfolding to neurodegeneration. Nature 2006, 441, 513-517. [CrossRef] 
49. Words, K. Neurofibrillary Tangles and Alzheimer's Disease. Curr. Opin. Neurobiol. 1998, 1, 130-140.

50. Lindholm, D.; Wootz, H.; Korhonen, L. ER stress and neurodegenerative diseases. Cell Death Differ. 2006, 13, 385-392. [CrossRef]

51. Shi, X.; Lu, X.; Zhan, L.; Liu, L.; Sun, M.Z.; Gong, X.; Sui, H.; Niu, X.; Liu, S.; Zheng, L.; et al. Rat hippocampal proteomic alterations following intrahippocampal injection of amyloid beta peptide (1-40). Neurosci. Lett. 2011, 500, 87-91. [CrossRef]

52. Rao, R.V.; Bredesen, D.E. Misfolded proteins, endoplasmic reticulum stress and neurodegeneration. Curr. Opin. Cell Biol. 2004, 16, 653-662. [CrossRef]

53. Khodagholi, F.; Digaleh, H.; Motamedi, F.; Foolad, F.; Shaerzadeh, F. Nitric Oxide and Protein Disulfide Isomerase Explain the Complexities of Unfolded Protein Response Following Intra-hippocampal A $\beta$ Injection. Cell. Mol. Neurobiol. 2016, 36, 873-881. [CrossRef]

54. Honjo, Y.; Ayaki, T.; Tomiyama, T.; Horibe, T.; Ito, H.; Mori, H.; Takahashi, R.; Kawakami, K. Decreased levels of PDI and P5 in oligodendrocytes in Alzheimer's disease. Neuropathology 2017, 37, 495-501. [CrossRef]

55. Tsang, A.H.K.; Chung, K.K.K. Oxidative and nitrosative stress in Parkinson's disease. Biochim. Biophys. Acta Mol. Basis Dis. 2009, 1792, 643-650. [CrossRef]

56. Xu, B.; Jin, C.H.; Deng, Y.; Liu, W.; Yang, T.Y.; Feng, S.; Xu, Z.F. Alpha-Synuclein Oligomerization in Manganese-Induced Nerve Cell Injury in Brain Slices: A Role of NO-Mediated S-Nitrosylation of Protein Disulfide Isomerase. Mol. Neurobiol. 2014, 50, 1098-1110. [CrossRef]

57. Kabiraj, P.; Marin, J.E.; Varela-Ramirez, A.; Zubia, E.; Narayan, M. Ellagic acid mitigates SNO-PDI induced aggregation of Parkinsonian biomarkers. ACS Chem. Neurosci. 2014, 5, 1209-1220. [CrossRef]

58. Goswami, P.; Gupta, S.; Biswas, J.; Joshi, N.; Swarnkar, S.; Nath, C.; Singh, S. Endoplasmic Reticulum Stress Plays a Key Role in Rotenone-Induced Apoptotic Death of Neurons. Mol. Neurobiol. 2016, 53, 285-298. [CrossRef]

59. Nakato, R.; Ohkubo, Y.; Konishi, A.; Shibata, M.; Kaneko, Y.; Iwawaki, T.; Nakamura, T.; Lipton, S.A.; Uehara, T. Regulation of the unfolded protein response via S-nitrosylation of sensors of endoplasmic reticulum stress. Sci. Rep. 2015, 5, 14812. [CrossRef]

60. Bruijn, L.I.; Miller, T.M.; Cleveland, D.W. Unraveling the Mechanisms Involved in Motor Neuron Degeneration in Als. Annu. Rev. Neurosci. 2004, 27, 723-749. [CrossRef]

61. Walker, A.K.; Farg, M.A.; Bye, C.R.; McLean, C.A.; Horne, M.K.; Atkin, J.D. Protein disulphide isomerase protects against protein aggregation and is S-nitrosylated in amyotrophic lateral sclerosis. Brain 2010, 133, 105-116. [CrossRef]

62. Chen, X.; Zhang, X.; Li, C.; Guan, T.; Shang, H.; Cui, L.; Li, X.M.; Kong, J. S-nitrosylated protein disulfide isomerase contributes to mutant SOD1 aggregates in amyotrophic lateral sclerosis. J. Neurochem. Neurochem. 2013, 124, 45-58. [CrossRef]

63. Jeon, G.S.; Nakamura, T.; Lee, J.S.; Choi, W.J.; Ahn, S.W.; Lee, K.W.; Sung, J.J.; Lipton, S.A. Potential effect of S-nitrosylated protein disulfide isomerase on mutant SOD1 aggregation and neuronal cell death in amyotrophic lateral sclerosis. Mol. Neurobiol. 2014, 49, 796-807. [CrossRef]

64. Yuan, J.; Bryant, K.F.; Coen, D.M.; Boyce, M.; Harding, H.P.; Jousse, C.; Ron, D.; Scheuner, D.; Long, K.; Ma, D.; et al. A Selective Inhibitor of eIF2\{alpha\} Dephosphorylation Protects Cells from ER Stress. Science 2005, 307, 935-939.

65. Halperin, L.; Jung, J.; Michalak, M. The many functions of the endoplasmic reticulum chaperones and folding enzymes. IUBMB Life 2014, 66, 318-326. [CrossRef]

66. Hetz, C.; Mollereau, B. Disturbance of endoplasmic reticulum proteostasis in neurodegenerative diseases. Nat. Rev. Neurosci. 2014, 15, 233-249. [CrossRef]

67. Thomas, C.J.; Parakh, S.; Perri, E.R.; Atkin, J.D.; Spencer, D.M. The Unfolded Protein Response and the Role of Protein Disulfide Isomerase in Neurodegeneration. Front. Cell Dev. Biol. 2016, 3, 1-17.

68. Gimzewski, J. XBP-1 Regulates a Subset of Endoplasmic Reticulum Resident Chaperone Genes in the Unfolded Protein Response. Mol. Cell. Biol. 2003, 23, 7448-7459.

69. Schröder, M.; Kaufman, R.J. ER stress and the unfolded protein response. Mutat. Res. Mol. Mech. Mutagen. 2005, 569, 29-63. [CrossRef]

70. Lee, K.P.K.; Dey, M.; Neculai, D.; Cao, C.; Dever, T.E.; Sicheri, F. Structure of the Dual Enzyme Ire1 Reveals the Basis for Catalysis and Regulation in Nonconventional RNA Splicing. Cell 2008, 132, 89-100. [CrossRef] 
71. Ali, M.M.U.; Bagratuni, T.; Davenport, E.L.; Nowak, P.R.; Silva-Santisteban, M.C.; Hardcastle, A.; McAndrews, C.; Rowlands, M.G.; Morgan, G.J.; Aherne, W.; et al. Structure of the Ire1 autophosphorylation complex and implications for the unfolded protein response. EMBO J. 2011, 30, 894-905. [CrossRef]

72. Yang, L.; Calay, E.S.; Fan, J.; Arduini, A.; Kunz, R.C.; Gygi, S.P.; Yalcin, A.; Fu, S.; Hotamisligil, G.S. S-Nitrosylation links obesity-associated inflammation to endoplasmic reticulum dysfunction. Science 2015, 349, 500-506. [CrossRef]

73. Han, J.; Kaufman, R.J. The role of ER stress in lipid metabolism and lipotoxicity. J. Lipid Res. 2016, 57, 1329-1338. [CrossRef]

74. Hotamisligil, G.S. Endoplasmic Reticulum Stress and the Inflammatory Basis of Metabolic Disease. Cell 2010, 140, 900-917. [CrossRef]

75. Perreault, M.; Marette, A. Targeted disruption of inducible nitric oxide synthase protects against obesity-linked insulin resistance in muscle. Nat. Med. 2001, 7, 1138-1143. [CrossRef]

76. Noronha, B.T.; Li, J.; Wheatcroft, S.B.; Shah, A.M.; Kearney, M.T. Inducible nitric oxide synthase has divergent effects on vascular and metabolic function in obesity. Diabetes 2005, 54, 1082-1089. [CrossRef]

77. Carvalho-filho, M.A.; Ueno, M.; Hirabara, S.M.; Seabra, A.B.; Carvalheira, B.C.; De Oliveira, M.G.; Velloso, A.; Curi, R.; Saad, M.J.A. S-Nitrosation of the Insulin Receptor, Insulin Receptor. Diabetes 2005, 54, 959-967. [CrossRef]

78. Siow, R.C.M.; Ishii, T.; Mann, G.E. Modulation of antioxidant gene expression by 4-hydroxynonenal: Atheroprotective role of the Nrf2/ARE transcription pathway. Redox Rep. 2007, 12, 11-15. [CrossRef]

79. Kikuta, K.; Masamune, A.; Satoh, M.; Suzuki, N.; Shimosegawa, T. 4-Hydroxy-2, 3-nonenal activates activator protein-1 and mitogen-activated protein kinases in rat pancreatic stellate cells. World J. Gastroenterol. 2004, 10, 2344-2351. [CrossRef]

80. Lee, S.J.; Seo, K.W.; Yun, M.R.; Bae, S.S.; Lee, W.S.; Hong, K.W.; Kim, C.D. 4-Hydroxynonenal enhances MMP-2 production in vascular smooth muscle cells via mitochondrial ROS-mediated activation of the Akt/NF-kB signaling pathways. Free Radic. Biol. Med. 2008, 45, 1487-1492. [CrossRef]

81. Chiarpotto, E.; Domenicotti, C.; Paola, D.; Vitali, A.; Nitti, M.; Pronzato, M.A.; Biasi, F.; Cottalasso, D.; Marinari, U.M.; Dragonetti, A.; et al. Regulation of rat hepatocyte protein kinase $C \beta$ isoenzymes by the lipid peroxidation product 4-hydroxy-2,3-nonenal: A signaling pathway to modulate vesicular transport of glycoproteins. Hepatology 1999, 29, 1565-1572. [CrossRef]

82. Suc, I.; Meilhac, O.; Lajoie-Mazenc, I.; Vandaele, J.; Jürgens, G.; Salvayre, R.; Negre-Salvayre, A. Activation of EGF receptor by oxidized LDL. FASEB J. 1998, 12, 665-671. [CrossRef]

83. Lovell, M.A.; Ehmann, W.D.; Mattson, M.P.; Markesbery, W.R. Elevated 4-hydroxynonenal in ventricular fluid in Alzheimer's disease. Neurobiol. Aging 1997, 18, 457-461. [CrossRef]

84. Markesbery, W.R.; Lovell, M.A. Four-hydroxynonenal, a product of lipid peroxidation, is increased in the brain in Alzheimer's disease. Neurobiol. Aging 1998, 19, 33-36. [CrossRef]

85. Selley, M.L. (E)-4-Hydroxy-2-nonenal may be involved in the pathogenesis of Parkinson's disease. Free Radic. Biol. Med. 1998, 25, 169-174. [CrossRef]

86. Renner, A.; Sagstetter, M.R.; Harms, H.; Lange, V.; Götz, M.E.; Elert, O. Formation of 4-hydroxy-2-nonenal protein adducts in the ischemic rat heart after transplantation. J. Hear. Lung Transplant. 2005, 24, 730-736. [CrossRef]

87. Lee, W.C.; Wong, H.Y.; Chai, Y.Y.; Shi, C.W.; Amino, N.; Kikuchi, S.; Huang, S.H. Lipid peroxidation dysregulation in ischemic stroke: Plasma 4-HNE as a potential biomarker? Biochem. Biophys. Res. Commun. 2012, 425, 842-847. [CrossRef]

88. Ohhira, M.; Ohtake, T.; Matsumoto, A.; Saito, H.; Ikuta, K.; Fujimoto, Y.; Ono, M.; Toyokuni, S.; Kohgo, Y. Immunohistochemical detection of 4-hydroxy-2-nonenal-modified-protein adducts in human alcoholic liver diseases. Alcohol. Clin. Exp. Res. 1998, 22, 145S-149S. [CrossRef]

89. Seki, S.; Kitada, T.; Yamada, T.; Sakaguchi, H.; Nakatani, K.; Wakasa, K. In situ detection of lipid peroxidation and oxidative DNA damage in non-alcoholic fatty liver diseases. J. Hepatol. 2002, 37, 56-62. [CrossRef]

90. Ross, C.A.; Poirier, M.A. Protein aggregation and neurodegenerative disease. Nat. Med. 2004, 10, S10-S17. [CrossRef]

91. Paschen, W. Shutdown of translation: Lethal or protective? Unfolded protein response versus apoptosis. J. Cereb. Blood Flow Metab. 2003, 23, 773-779. [CrossRef] 
92. Zatloukal, K.; Stumptner, C.; Fuchsbichler, A.; Heid, H.; Schnoelzer, M.; Kenner, L.; Kleinert, R.; Prinz, M.; Aguzzi, A.; Denk, H. p62 is a common component of cytoplasmic inclusions in protein aggregation diseases. Am. J. Pathol. 2002, 160, 255-263. [CrossRef]

93. West, J.D.; Marnett, L.J. Alterations in gene expression induced by the lipid peroxidation product, 4-hydroxy-2-nonenal. Chem. Res. Toxicol. 2005, 18, 1642-1653. [CrossRef]

94. Vladykovskaya, E.; Sithu, S.D.; Haberzettl, P.; Wickramasinghe, N.S.; Merchant, M.L.; Hill, B.G.; McCracken, J.; Agarwal, A.; Dougherty, S.; Gordon, S.A.; et al. Lipid peroxidation product 4-hydroxy-trans-2-nonenal causes endothelial activation by inducing endoplasmic reticulum stress. J. Biol. Chem. 2012, 287, 11398-11409. [CrossRef]

95. Haberzettl, P.; Hill, B.G. Oxidized lipids activate autophagy in a JNK-dependent manner by stimulating the endoplasmic reticulum stress response. Redox Biol. 2013, 1, 56-64. [CrossRef]

96. Siems, W.; Grune, T. Intracellular metabolism of 4-hydroxynonenal. Mol. Asp. Med. 2003, 24, 167-175. [CrossRef]

97. Muller, C.; Bandemer, J.; Vindis, C.; Camaré, C.; Mucher, E.; Guéraud, F.; Larroque-Cardoso, P.; Bernis, C.; Auge, N.; Salvayre, R.; et al. Protein Disulfide Isomerase Modification and Inhibition Contribute to ER Stress and Apoptosis Induced by Oxidized Low Density Lipoproteins. Antioxid. Redox Signal. 2013, 18, 731-742. [CrossRef]

98. Carbone, D.L.; Doorn, J.A.; Kiebler, Z.; Sampey, B.P.; Petersen, D.R. Inhibition of Hsp72-mediated protein refolding by 4-hydroxy-2-nonenal. Chem. Res. Toxicol. 2004, 17, 1459-1467. [CrossRef]

99. Carbone, D.L. Modification of Heat Shock Protein 90 by 4-Hydroxynonenal in a Rat Model of Chronic Alcoholic Liver Disease. J. Pharmacol. Exp. Ther. 2005, 315, 8-15. [CrossRef]

100. Ota, A.; Wang, Y. Cdc37/Hsp90 protein-mediated regulation of IRE1 $\alpha$ protein activity in endoplasmic reticulum stress response and insulin synthesis in INS-1 cells. J. Biol. Chem. 2012, 287, 6266-6274. [CrossRef]

101. Pincus, D.; Chevalier, M.W.; Aragón, T.; van Anken, E.; Vidal, S.E.; El-Samad, H.; Walter, P. BiP binding to the ER-stress sensor Ire1 tunes the homeostatic behavior of the unfolded protein response. PLoS Biol. 2010, 8, e1000415. [CrossRef]

102. Hauswirth, W.W.; Petrs-Silva, H.; AdÃ£o-Novaes, J.; Linden, R.; Cabral Miranda, F.; Chiarini, L.B. CHIP, a carboxy terminus HSP-70 interacting protein, prevents cell death induced by endoplasmic reticulum stress in the central nervous system. Front. Cell. Neurosci. 2015, 8, 438.

103. Matsumura, Y.; Sakai, J.; Skach, W.R. Endoplasmic reticulum protein quality control is determined by cooperative interactions between Hsp/c70 protein and the CHIP E3 ligase. J. Biol. Chem. 2013, 288, 31069-31079. [CrossRef]

104. Farout, L.; Mary, J.; Vinh, J.; Szweda, L.I.; Friguet, B. Inactivation of the proteasome by 4-hydroxy-2-nonenal is site specific and dependant on $20 \mathrm{~S}$ proteasome subtypes. Arch. Biochem. Biophys. 2006, 453, 135-142. [CrossRef]

105. Clarkson, T.W.; Magos, L.; Myers, G.J. The Toxicology of Mercury-Current Exposures and Clinical Manifestations. N. Engl. J. Med. 2003, 349, 1731-1737. [CrossRef]

106. Yin, Z.; Jiang, H.; Syversen, T.; Rocha, J.B.T.; Farina, M.; Aschner, M. The methylmercury-L-cysteine conjugate is a substrate for the L-type large neutral amino acid transporter. J. Neurochem. 2008, 107, 1083-1090. [CrossRef]

107. Simpson, R.B. Association Constants of Methylmercury with Sulfhydryl and Other Bases. J. Am. Chem. Soc. 1961, 83, 4711-4717. [CrossRef]

108. Kanda, H.; Shinkai, Y.; Kumagai, Y. S-Mercuration of cellular proteins by methylmercury and its toxicological implications. J. Toxicol. Sci. 2014, 39, 687-700. [CrossRef]

109. Cheung, M.K.; Verity, M.A. Experimental Methyl Mercury Neurotoxicity: Locus of Mercurial Inhibition of Brain Protein Synthesis In Vivo and In Vitro. J. Neurochem. 1985, 44, 1799-1808. [CrossRef]

110. Vogel, D.G.; Margolis, R.L.; Mottet, N.K. The effects of methyl mercury binding to microtubules. Toxicol. Appl. Pharmacol. 1985, 80, 473-486. [CrossRef]

111. Kumagai, Y.; Homma-Takeda, S.; Shinyashiki, M.; Shimojo, N. Alterations in Superoxide Dismutase Isozymes by Methylmercury. Appl. Organomet. Chem. 1997, 11, 635-643. [CrossRef]

112. Mori, N.; Yasutake, A.; Hirayama, K. Comparative study of activities in reactive oxygen species production/defense system in mitochondria of rat brain and liver, and their susceptibility to methylmercury toxicity. Arch. Toxicol. 2007, 81, 769-776. [CrossRef] 
113. Ichijo, H.; Nishida, E.; Irie, K.; ten Dijke, P.; Saitoh, M.; Moriguchi, T.; Takagi, M.; Matsumoto, K.; Miyazono, K.; Gotoh, Y. Induction of apoptosis by ASK1, a mammalian MAPKKK that activates SAPK/JNK and p38 Signaling Pathways. Science 1997, 275, 90-94. [CrossRef]

114. Usuki, F.; Fujita, E.; Sasagawa, N. Methylmercury activates ASK1/JNK signaling pathways, leading to apoptosis due to both mitochondria-and endoplasmic reticulum (ER)-generated processes in myogenic cell lines. Neurotoxicology 2008, 29, 22-30. [CrossRef]

115. Nishitoh, H.; Matsuzawa, A.; Tobiume, K.; Saegusa, K.; Takeda, K.; Hori, S.; Kakizuka, A.; Ichijo, H. ASK1 is essential for endoplasmic reticulum stress-induced neuronal cell death triggered by expanded polyglutamine repeats. Genes Dev. 2002, 16, 1345-1355. [CrossRef]

116. Liu, W.; Yang, T.; Xu, Z.; Xu, B.; Deng, Y. Methyl-mercury induces apoptosis through ROS-mediated endoplasmic reticulum stress and mitochondrial apoptosis pathways activation in rat cortical neurons. Free Radic. Res. 2018, 53, 26-44. [CrossRef]

117. Makino, K.; Okuda, K.; Sugino, E.; Nishiya, T.; Toyama, T.; Iwawaki, T.; Fujimura, M.; Kumagai, Y.; Takashi, U. Correlation Between Attenuation of Protein Disulfide Isomerase Activity Through S-Mercuration and Neurotoxicity Induced by Methylmercury. Neurotox. Res. 2014, 27, 99-105. [CrossRef]

118. Nakagawa, T.; Zhu, H.; Morishima, N.; Li, E.; Xu, J.; Yankner, B.A.; Yuan, J. Caspase-12 mediates endoplasmic reticulum specific apoptosis and cytotoxicity by amyloid-b. Nature 2000, 403, 98-103. [CrossRef]

119. Hiraoka, H.; Nakahara, K.; Kaneko, Y.; Akiyama, S.; Okuda, K.; Iwawaki, T.; Fujimur, M.; Kumagai, Y.; Takasugi, N.; Uehara, T. Modulation of unfolded protein response by methylmercury. Biol. Pharm. Bull. 2017, 40, 1595-1598. [CrossRef]

120. Chen, H.; Yang, H.; Pan, L.; Wang, W.; Liu, X.; Ren, X.; Liu, Y.; Liu, W.; Zhang, Y.; Jiang, L.; et al. The molecular mechanisms of XBP-1 gene silencing on IRE1 $\alpha$-TRAF2-ASK1-JNK pathways in oral squamous cell carcinoma under endoplasmic reticulum stress. Biomed. Pharmacother. 2016, 77, 108-113. [CrossRef]

121. Fujimura, M.; Usuki, F.; Sawada, M.; Takashima, A. Methylmercury induces neuropathological changes with tau hyperphosphorylation mainly through the activation of the c-jun-N-terminal kinase pathway in the cerebral cortex, but not in the hippocampus of the mouse brain. Neurotoxicology 2009, 30, 1000-1007. [CrossRef]

122. Martinez-Finley, E.J.; Caito, S.; Slaughter, J.C.; Aschner, M. The role of skn-1 in methylmercury-induced latent dopaminergic neurodegeneration. Neurochem. Res. 2013, 38, 2650-2660. [CrossRef]

123. Shao, Y.; Figeys, D.; Ning, Z.; Mailloux, R.; Chan, H.M. Methylmercury can induce Parkinson's-like neurotoxicity similar to 1-methyl-4-phenylpyridinium: A genomic and proteomic analysis on MN9D dopaminergic neuron cells. J. Toxicol. Sci. 2015, 40, 817-828. [CrossRef]

124. Bailey, J.M.; Colón-Rodríguez, A.; Atchison, W.D. Evaluating a Gene-Environment Interaction in Amyotrophic Lateral Sclerosis: Methylmercury Exposure and Mutated SOD1. Curr. Environ. Health Rep. 2017, 4, $200-207$. [CrossRef]

125. Kern, J.K.; Geier, D.A.; Homme, K.G.; King, P.G.; Bjørklund, G.; Chirumbolo, S.; Geier, M.R. Developmental neurotoxicants and the vulnerable male brain: A systematic review of suspected neurotoxicants that disproportionally affect males. Acta Neurobiol. Exp. 2017, 77, 269-296. [CrossRef]

126. Kupsco, A.; Schlenk, D. Oxidative Stress, Unfolded Protein Response, and Apoptosis in Developmental Toxicity. Int. Rev. Cell Mol. Biol. 2015, 317, 1-66.

127. Kawada, K.; Mimori, S. Implication of Endoplasmic Reticulum Stress in Autism Spectrum Disorder. Neurochem. Res. 2018, 43, 138-143. [CrossRef]

128. Kurtishi, A.; Rosen, B.; Patil, K.S.; Alves, G.W.; Moller, S.G. Cellular Proteostasis in Neurodegeneration. Mol. Neurobiol. 2018. [CrossRef]

129. García-González, P.; Cabral-Miranda, F.; Hetz, C.; Osorio, F. Interplay Between the Unfolded Protein Response and Immune Function in the Development of Neurodegenerative Diseases. Front. Immunol. 2018, 9, 1-10. [CrossRef]

130. Lien, J.C.; Huang, C.C.; Lu, T.J.; Tseng, C.H.; Sung, P.J.; Lee, H.Z.; Bao, B.Y.; Kuo, Y.H.; Lu, T.L. Naphthoquinone derivative PPE8 induces endoplasmic reticulum stress in p53 Null H1299 cells. Oxid. Med. Cell. Longev. 2015, 2015, 1-10. [CrossRef]

131. Kitaguchi, Y.; Taraseviciene-Stewart, L.; Hanaoka, M.; Natarajan, R.; Kraskauskas, D.; Voelkel, N.F. Acrolein induces endoplasmic reticulum stress and causes airspace enlargement. PLoS ONE 2012, 7, e38038. [CrossRef] 
132. Tanel, A.; Pallepati, P.; Bettaieb, A.; Morin, P.; Averill-Bates, D.A. Acrolein activates cell survival and apoptotic death responses involving the endoplasmic reticulum in A549 lung cells. Biochim. Biophys. Acta Mol. Cell Res. 2014, 1843, 827-835. [CrossRef]

133. Haberzettl, P.; Vladykovskaya, E.; Srivastava, S.; Bhatnagar, A. Role of endoplasmic reticulum stress in acrolein-induced endothelial activation. Toxicol. Appl. Pharmacol. 2009, 234, 14-24. [CrossRef]

134. Saito, S.; Takahashi, S.; Takagaki, N.; Hirose, T.; Sakai, T. 15-Deoxy- $\Delta 12,14$-prostaglandin J2 induces apoptosis through activation of the CHOP gene in HeLa cells. Biochem. Biophys. Res. Commun. 2003, 311, 17-23. [CrossRef]

135. Kansanen, E.; Kivelä, A.M.; Levonen, A.L. Regulation of Nrf2-dependent gene expression by 15-deoxy- $\Delta 12,14-$ prostaglandin J2. Free Radic. Biol. Med. 2009, 47, 1310-1317. [CrossRef]

(C) 2019 by the authors. Licensee MDPI, Basel, Switzerland. This article is an open access article distributed under the terms and conditions of the Creative Commons Attribution (CC BY) license (http://creativecommons.org/licenses/by/4.0/). 